particularly on the part of France and West Germany, to earn maximum export dollars from nuclear trade, and of deep European suspicions of American motives. According to some observers, there is concern in Europe that American attempts to prevent the German-Brazil deal, in particular, were chiefly designed to protect the United States' commercial interests there.

Such suspicions were given a blast of fertiliser last year by an incident which occurred just as the United States was applying pressure on West Germany not to conclude its fuel technology agreement with Brazil. According to published accounts, a representative of the Bechtel Power Corporation, a major US nuclear manufacturer, met in March last year with Brazilian officials to discuss the possibility of building fuel facilities there, leaving the impression that the US government would sanction such a deal. Though the incident was probably simply a product of poor communications between industry and government in the United States, it clearly left a sour impression in Europe. Moreover, it should be noted that while Dr Ikle has been arguing that there is no economic incentive for recycling plutonium at present, the US nuclear industry has been urging the government to allow plutonium recycling in the United States.

If the provision in the foreign aid bill survives the rest of the Con- gressional mill intact, however, it would greatly stiffen the administration's policies in trying to dissuade the sale of enrichment and reprocessing technology. Proposed by Senator Stuart Symington, it would cut off nearly all US aid to the buyers and sellers of such technology, unless they have agreed to "place all such equipment, materials, and technology, upon delivery, under multilateral auspices and management when available", and unless the recipient agrees to place all its nuclear facilities under IAEA safeguards. The latter provision is intended to prevent the recipient from either duplicating the reprocessing or enrichment technology, or separating plutonium from an unsafeguarded reactor in the transferred reprocessing plant. The amendment is not, however, included in the House version of the bill, and its prospects are uncertain.

As for safeguards on the sale of power reactors, the Administration's policy is that controls should be applied uniformly among the supplying countries rather than imposed unilaterally, the argument being that if the United States insists on excessively strict safeguards on its own sales, potential purchasers will simply look elsewhere. Key issues in next month's talks are likely to include ways to bring presently unsafeguarded reactors and facilities into the IAEA safeguards system, methods to ensure that promises not to use imported nuclear technology for weapons production are made binding, and strengthening of the IAEA safeguards and inspection system.

Aside from the suppliers' conference, Mr Jimmy Carter, the leading candidate to be the Democratic Party's Presidential nominee, has called for a UN-sponsored World Energy Conference to discuss worldwide energy problems and alternatives to nuclear power. Calling nuclear proliferation a "fearsome prospect", Carter also urged a ban on sales of reprocessing and enrichment technology, and he called for a pact among purchasers of nuclear technology to buy only from suppliers who require proper safeguards. "The hour is too late for business as usual", he said. So far, nobody else has talked about those issues in the campaign.

The outcome of the exporters' conference is clearly going to be of immense importance. As Denis Hayes, a researcher with the Worldwatch Institute noted in a recent study on nuclear power, if a few more nations acquire nuclear weapons, there will come a point at which the "dam will break and the world will go nuclear". And, in Congressional testimony earlier this year, David Lilienthal, the first chairman of the US Atomic Energy Commission called for an immediate, unilateral halt to all US nuclear exports because of the dangers of proliferation. "I'm glad I'm not a young man", he said, and "I'm sorry for my grandchildren".

The latest news probably means that the efforts to reach international understandings on nuclear exports have suffered something of a setback. But the Canadian government has meanwhile been pursuing its chosen path in negotiations with other countries. Canada hopes to obtain an agreement with Pakistan not to use plutonium from a Canadian-designed nuclear powe $r$ plant, and in January concluded agreements to build 600 megawatt power reactors in Argentina and South Korea. An Atomic Energy of Canada Ltd (AECL) spokesman has said there is the prospect of building second units in Argentina and South Korea in future, and preliminary discussions have been undertaken with other countries, including Mexico. Canada is also involved in licensing negotiations with Italy and Romania. Altogether, expected exports of CANDU reactors between 1974 and 1983 have been estimated by the federal department of industry, trade and commerce to amount to $\$ 3,000$ million.

The debate over the propriety of Canada's selling nuclear reactors and technology when world powers are con- 
cerned about the proliferation of nuclear weapons has gone beyond Parliament. The Prime Minister has received delegations from the Canadian Council of Churches, the United Church of Canada, and the Quakers, and he has been urged to call a halt to the sales. The irony is that the CANDU nuclear reactor has turned out to be one of the most successful in the world at a time when confidence in reactor reliability is waning throughout the world and construction starts are falling off. Canada went it alone with its design (the CANDU is moderated by heavy water and fuelled with natural uranium), and finally appears able, as a result of worldwide interest, to recoup some of its huge investment made over the years.

Critics of the government's policy have expressed fears that CANDU reactors will be used to recover plutonium (produced as a by-product) for the making of nuclear weapons. In the eyes of T. C. Douglas, the former leader of the New Democratic Party, for example, "Canada has greater special responsibility than any other country"; the CANDU reactor, he points out, produces twice as much plutonium as light-water reactors, and spent-fuel rods containing plutonium can be removed daily without shutting down the reactor. On the other hand, Frank Maine, a Liberal MP with a $\mathrm{PhD}$ in organic chemistry who is one of the few members of the House with a background in science, has claimed that there are "technical reasons why the CANDU does not contribute to the proliferation of nuclear weapons."

The argument was put in these terms. Since the CANDU is fuelled with natural uranium it converts a lot of its primary fuel component, Uranium 238 , into Plutonium 239 and Plutonium 240. Plutonium 239 is used primarily to make bombs, but Plutonium 240 is not very useful for bomb-making. The operating conditions for bomb-making and electricity-generation, however, are contradictory in a CANDU reactor: the longer the fuel is left in the reactor, the more plutonium 240 is made; the shorter the time, the more plutonium 239; but the longer the reactor is left running without changing fuel, the more economic it is. To make plutonium for a bomb, the fuel rods must be left in the reactor for perhaps 600 megawatt days per tonne; but if economic electricity production is wanted, the rods must be left in for 6,000 megawatt days.

Thus, said Dr Maine, the CANDU system is "a total design":

It is designed to be fed the fuel continuously, and the feeding of the reactor is such that the uranium will be irradiated to the 6,000 megawatt days per tonne level.

If you change it by a factor of ten, either you have to redesign your system completely .... or else you will have to shut the system down to take out the fuel . . . if you want to generate electricity you use the CANDU system, but if you want to make bombs you do not use the CANDU system.

Dr Maine's technical arguments had little effect on the debates. What bothered many of the opposition members was what they considered a secretive attitude on the part of the government concerning its negotiations with India. $\mathrm{Mr}$ Douglas complained that when newspaper reports first appeared about the Delhi delegation and inquiries were made, the Secretary of State for External Affairs "said that the delegation was in India and until it returned he was not in a position to say what agreement it might be discussing". When the delegation did return, "he said the matter was before Cabinet and he could not discuss it until a decision had been made."

Another aspect that bothered critics was that they felt they did not know exactly what was decided at the meetings in London of the "Group of Scven". The Government's position has been that it cannot in good conscience withhold from developing countries the technology they need to help supply their power requirements. $\mathrm{Mr}$ MacEachen has also claimed that Canada has had considerable influence in upgrading nuclear standards among the suppliers, and that if Canada withdrew from the export market it would lose this influence. There would also be domestic consequences, such as a radical dislocation of the uranium mining industry. "If we want to succeed in the task of ensuring nonproliferation, we must cast the net wider", Mr MacEachen told the Commons. "We must consider the causes of international tension and do something about the disparities that exist in the world. We must do something to bring about a better and more equitable international economic system."

In addition to the CIRUS research reactor from which India obtained the plutonium for its nuclear explosive device, Canada has helped to build two reactors known as RAPP-I and RAPPII. Completion of the second has been held up by Canada's decision not to

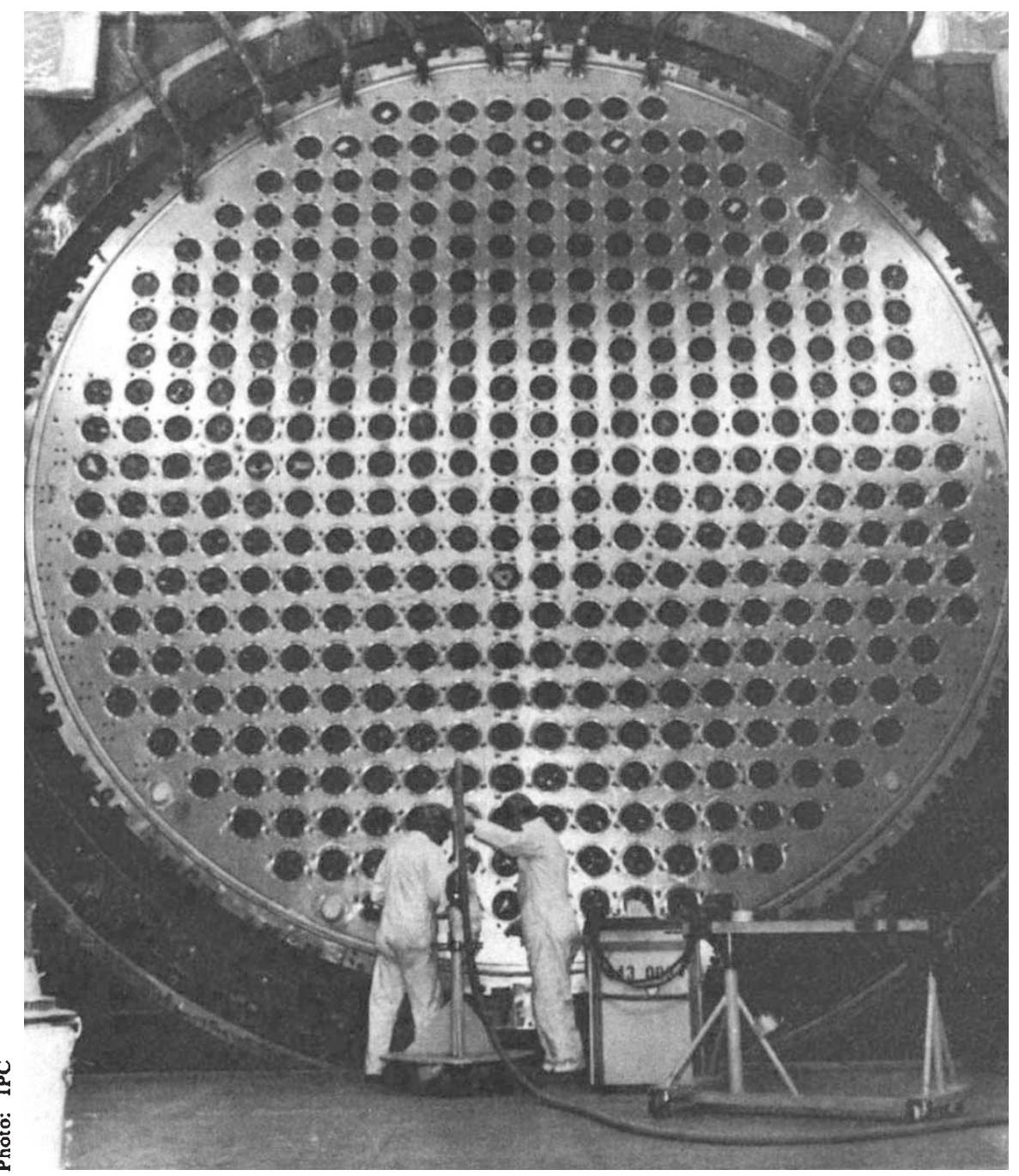

What the fuss is all about: part of a $C A N D U$ reactor 
supply further nuclear assistance without assurance that plutonium coming from it will not be used for further nuclear explosions. It is the lack of that assurance which is chiefly responsible for last week's announcement. The Canadian government has wanted to upgrade the safeguard system which already exists on RAPP-II, which India is capable of finishing alone, though it will take longer without Canadian help.

According to $\mathrm{Mr}$ MacEachen, the question the government has been faced with is whether it is better in the interests of non-proliferation to get out of nuclear co-operation with India completely, risking a collapse of current safcguards, or to complete the project while upgrading the RAPP-II safeguards. The crucial point, however, concerns the absence of safeguards on the very reactor that produced India's first nuclear explosion-the CIRUS. CIRUS would not have been covered by the agreement, Canadian officials apparently thinking it unimportant because it produces only enough plutonium to make one or two bombs a year. Furthermore, future reactors now being built or planned by India to Canadian design would not have been safeguarded by the terms of the Canadian agrecment.

Before the latest decision the rationale that the government was using seemed to ignore the very rationale Frank Maine had put forward to defend it: that, because the RAPP reactors are designed to produce power, they could only be used to produce weapons-grade plutonium at the expense of power production. On the other hand, a research reactor like CIRUS is ideal for producing fissile material. That, in fact, is what was done two years ago.

Another question critics asked was how much Canada could rely on safeguards even if they were agreed to. Canada thought it had agreement from India that she would not explode a nuclear device before she actually did so. "Safeguards," said T. C. Douglas, "are worth nothing unless the people who give them are the kind of people on whom we can rely." Robert Stanfield, the former opposition leader, wondered if "the government and those who are advising the government are not acting on the premise that these potential customers are going to get the bomb anyway, and Canada might as well get the business".

There has been some indication that a firm stand by Canada does have some effect. South Korea cancelled a fuel reprocessing plant under pressurc from the United States and Canada when Canada threatened to cancel construction of its nuclear plant. Pakistan has contracted with France to buy a processing plant-for reasons unsatisfactory to Canada-and Canada was hoping that if its agreement with India was successfully concluded it would obtain a similar agreement with Pakistan. Such an agreement would prevent Pakistan from using explosive devices from waste fuel from a Canadian-designed plant in Karachi. Until it receives a commitment, Canada will not supply Pakistan with a plant to make fuel bundles for the Karachi reactor, and has threatened to hold back delivery of fuel made in Canada.

What the Canadian nuclear export critics have been saying is that Canada should undertake a moratorium on sales of nuclear materials for a period, during which pressure should be exerted on other exporting countries to agree on adequate safeguards, with sanctions. With respect to India at least, the Cabinet has now made a decision, and through its external affairs minister the Indian government has already expressed its regret and disappointment. The full background behind the Canadian announcement has yet to emerge-India quickly disclaimed any responsibility on her part -and the forthcoming meeting of the "Group of Seven" has now taken on added interest.

\section{CHEMICAL WEAPONS}

\section{Slow progress to disarmament}

Attempts are being made to reduce, through international understandings, the chances of chemical warfare. John Stares outlines some of the problems

Drawing up an international treaty banning chemical weapons ought to be a simple matter. Chemical warfare has been illegal for more than 50 years. No chemical weapons have been manufactured, at least in the West, for almost 10 years, and some countrics have begun to dispose of their obsolete stocks. Admittedly a new generation of chemical weapons-the binary weapons-is being developed in the United States, but the US Congress has so far refused to grant funds for their manufacture. And yet, in almost 10 years of international negotiations, the Conference of the Committee on Disarmament (CCD) in Geneva has failed to produce a chemical disarmament treaty.

As time goes on, the need for a chemical warfare (CW) treaty becomes more urgent. Details of the chemistry of $\mathrm{CW}$ agent production are widely known, and there is a growing risk of the proliferation of chemical weapons. Advances in our knowledge of biochemistry, and developments in genetic engineering, bring with them the danger of the development of new $\mathrm{CW}$ agents. It may only be a matter of time before the US Congress does grant procurement funds for binaries. If proliferation, the development of new agents or procurement of binarics does become reality, the problems of reaching agreement on chemical disarmament will increase considerably. But in a major specch to the CCD last month, the US delegate, Joseph Martin, indicated that agreement is still a long way off.

Ambassador Martin said that there are several issues where, in the US view, "an adequate basis for forming judgments already seems to exist, and where agreement may be possible in the relatively near future". On the question of the scope of a $\mathrm{CW}$ treaty, he said that "the complete prohibition of chemical weapons cannot be realised in a single comprehensive agreement", and that therefore there should be a phased approach to chemical dis- armament. A step-by-step approach is not a new idea, but while in the past the aim was to concentrate initially on the most dangerous "supertoxic" CW agents, such as the nerve gases, it is now generally agreed that an initial CW treaty should encompass all lethal CW agents.

Thus the phased approach to chemical disarmament should be based on the activities to be included in the ban. Initially attention should be focused on banning the production of all lethal CW agents, and on reducing existing stockpiles, although exactly what measures should be applied to stocks-. whether, for example, the treaty should require destruction of all, or only part, of the stocks-is still a matter for debate.

On the question of the definition of CW agents, it is the "tentative view" of the USA that it might be adequate to rely on a general purpose criterion -perhaps along the lines of the formulation in the 1974 Japanese draft CW treaty, where CW agents were defined as chemicals "of types and in quantities that have no justification for protective or other peaceful purposes" -and on lethal toxicity standards. Other criteria, such as representative lists of agents, or structural formulae, 